\title{
ВЫБОР ПАРАМЕТРОВ ФЕРРИТОВОГО ЭЛЕМЕНТА ДЛЯ ИМПУЛЬСНОЙ СШП ПРИЕМНОЙ АНТЕННЫ
}

\author{
ОГУРЦОВА Т. Н. \\ Институт радиофизики и электроники Национальной Академии наук Украины,, \\ Украина, Харьков, 61085, ул. Проскуры 12
}

\begin{abstract}
Аннотация. Исследована теоретическая модель импульсной сверхширокополосной (СШП) приемной антенны, состоящей из ферритового элемента, охваченного витком проводника. В качестве ферритового элемента выбран магнитодиэлектрический цилиндр бесконечной длины. Возбуждающий СШП сигнал представляет собой импульс электромагнитного поля с огибающей в виде функции Гаусса с высокочастотным заполнением. Рассмотрены особенности амплитудно-временной зависимости импульса электродвижущей силы индукции, возникающего в охватывающем цилиндр замкнутом проводящем контуре, в приближении отсутствия его влияния на рассеянные поля внутри и вне цилиндра. Определена взаимосвязь между электродинамическими параметрами ферритового элемента и частотно-временными параметрами возбуждающего импульсного электромагнитного поля, оптимальными с точки зрения эффективного неискаженного приема сигнала.
\end{abstract}

Ключевые слова: импульсное электромагнитное поле; сверхширокополосный импульсный сигнал; приемная антенна; магнитодиэлектрический цилиндр; замкнутый контур; дифракция; импульс электродвижущей силы

\section{ВВЕДЕНИЕ}

Расширение возможностей традиционной радиолокации с целью распознавания и восстановления формы объекта по характеристикам рассеянного поля, исследование полей, возникающих при воздействии электромагнитных сигналов на различные объекты, связано с использованием временно и пространственно ограниченных полей (импульсов) с разнообразными видами огибающей и шириной частотного спектра [1-5]. В частности, такие импульсы широко применяются для решения задач подповерхностного зондирования. В этой области радиолокации актуальной остается задача построения малогабаритной импульсной сверхширокополосной (СШП) приемной антенны, обладающей высокой чувствительностью, и не искажающей форму принимаемого сигнала.

В качестве таких антенн возможно использовать ферритовые рамочные антенны. Внесение ферритового сердечника в рамочную антенну позволяет повысить ее чувствительность и существенно уменьшить габариты. Известно большое количество работ, направленных на решение проблем расширения рабочего диапазона частот ферритовых антенн и повышения их чувствительности [4, 6, 7-11].

Принцип действия ферритовой антенны, состоящей из проводящей рамки, внутри которой расположен стержень из низкочастотного феррита, аналогичен принципу работы широкополосного импульсного трансформатора и позволяет использовать одновременно два механизма преобразования напряженности реги- 


\section{БИБЛИОГРАФИЧЕСКИЙ СПИСОК}

1. Ширман Я. Д. О первых отечественных исследованиях по СШП локации / Я. Д. Ширман // Радиотехника и электроника. - 1991. - Т. 36, №1. C. $96-100$.

2. Хармут $X . \Phi$. Несинусоидальные волны в радиолокации и связи / Х. Ф. Хармут ; пер. с англ. под ред. А. П. Мальцева. - М. : Радио и связь, 1985. $376 \mathrm{c}$.

3. Астанин Л. Ю. Основы сверхширокополосных радиолокационных измерений / Л. Ю. Астанин, А. А. Костылев. - М. : Радио и связь, 1989. - 192 с.

4. Масалов С. А. СШП рамочные передающие и приемные антенны / С. А. Масалов, Г. П. Почанин, П. В. Холод // Вопросы подповерхностной радиолокации ; под ред. А. Ю. Гринева. - М. : Радиотехника, 2005. - Гл. 18. - С. 344-372.

5. Лазоренко О. В. Сверхширокополосные сигналы и физические процессы. 1. Основные понятия, модели и методы описания / О. В. Лазоренко, Л. Ф. Черногор // Радиофизика и радиоастрономия. - 2008. T. 13, № 2. - С. 166-194. - Режим доступа : http://journal.rian.kharkov.ua/index.php/ra/article/view/5 $\underline{67}$.

6. Фрадин А. 3. Антенно-фидерные устройства / А. 3. Фрадин. - М. : Связь, 1977. — 440 с.
7. Хомич В. И. Приемные ферритовые антенны: массовая радиобиблиотека / В. И. Хомич. - М.-Л. : Госэнергоиздат, 1960. - Вып. 370. - 64 с.

8. А.с. 1681356 СССР, МКИ Н01Q 7/06. Магнитная антенна / В. В. Крымский. — № 4349964/09 ; заявл. 26.12.87 ; опубл. 30.09.91, Бюл. № 36. - С. 35 .

9. Пат. 2256264 Российская Федерация, H01Q7/08. Широкополосная приемная ферритовая антенна с комбинированным сердечником / А. М. Бобков. — № 2004110863/09 ; заявл. 2004.04.06 ; опубл. 2005.07.10.

10. Пат. 2380801 Российская Федерация, H01Q. — Конструкция широкополосной приемной ферритовой антенны с улучшенным экранированием / А. М. Бобков. - Опубл. 2010.27.01.

11. Ogurtsova T. N. Sensitivity of UWB ferrite receiving antennas / T. N. Ogurtsova, G. P. Pochanin, P. V. Kholod // Ultrawideband and Ultrashort Impulse Signals : 2nd Int. Workshop, 19-22 Sept. 2004, Sevastopol, Ukraine : proc. — IEEE, 2004 — P. 279-281. — DOI : 10.1109/UWBUS.2004.1388129.

12. Баум К. Э. Новые методы нестационарного (широкополосного) анализа и синтеза антенн и рассеивателей / К. Э. Баум // ТИИЭР. - 1976. — Т. 64, № 11. - С. 53-74.

13. Кравченко В. Ф. Преобразование и излучение электромагнитных волн открытыми резонансными структурами. Моделирование и анализ переходных и установившихся процессов / В. Ф. Кравченко, Ю. К. Сиренко, К. Ю. Сиренко. - М. : Физматлит, 2011. — 320 c. - ISBN : 978-5-9221-1310-6.

14. Ogurtsova T. N. Excitation of an electromagnetic field pulse in the magnetodielectric cylinder $/ \mathrm{T}$. N. Ogurtsova, G. P. Pochanin, Yu. B. Sidorenko // Telecom. Radio Eng. - 2013. - Vol. 72, No. 9. P. 777-789. - DOI: 10.1615/TelecomRadEng.v72.i9.40.

15. Огуриова Т. Н. Возбуждение потока магнитной индукции внутри магнитодиэлектрического цилиндра / Т. Н. Огурцова, Ю. Б. Сидоренко // Радиофизика и электроника. - 2009. - Т. 14, № 3. C. 259-266.

16. Зернов Н.В. О решении нестационарных краевых задач электродинамики / Н. В. Зернов // ДАН CССР. - 1951. - Т. 30, № 1. - C. 33-35.

17. Орленко А. А. Активная антенна-зонд для измерения параметров импульсных электрических полей наносекундной длительности / А. А. Орленко, П. В. Холод // Радиофизика и электроника. - 2000. Т. 5, № 2. - С. 128-133.

18. Бозорт Р. Ферромагнетизм / Р. Бозорт. - М. : ИЛ, $1956 .-784 \mathrm{c}$. 